food, together with certain old local attributions, such as the 'pride of Peterborough' (103), make up great part of its contents. Blie and Bredeport perhaps and Stamford seem to appear twice $(12,65 ; 56$, 90 ; and 11,99). Cord is the staple of two places, Bridport and Warwick $(55,90)$. Three districts of London come in $(\tilde{5}, 6,7)$, as well as King's Cross and Westminster $(16,4)$. One notes mention of the Grahams, Stonehenge, the archers of Wales (?), the furriers of Chester (known from Domesday), the soap of Coventry, the school of Oxford, the ladies of Bury St. Edmunds, the damsels of Hertford, the barony of London, the bachelery of Northampton, and the villeins of Tamworth. The Worcester rymors are very near the Welsh border. There are traces of classification, dress, hardware, food, \&c. The last line of the final quatrain is obscure, and I cannot yet explain $49,51,54,56,62,79,83,88,91,92$; in a few cases, e.g. 62,83 , the text is incorrect.

C. BONNier.

\title{
A DIARY OF THE EXPEDITION OF 154.
}

A manuscript in the Cambridge University library, Dd. 14. 30 (3), contains an account of the expedition of 1544 , written by a steward who lived at Lydingetone. The writer gives more detail than will be found in the diary printed in Rymer's 'Foedera,' xv. 52, but his narrative breaks off abruptly at a very early stage.

\section{W. A. J. ARChвoLD.}

The iij day of July ao xxxvj H. 8. the Noble prynce Charles Duke of Suffoke Henry lorde marques Dorsset and Sir Anthony Browen lingght $\mathrm{M}^{\mathrm{r}}$ of the kynges mayeste horsses and of his graces priuye Chamber with dyuers other gent[ilmen] set forth frome Douer to Callys in a shyp callyd [ '] and the sayd Duke of Suffoke cansed the $\mathrm{m}^{\mathrm{r}}$ of the same ship or the Captayne therof callyd Adam Owtlaw to set in the toppe of the same a flage of Synt George whervnto cam the lord admirall of Englond and $\mathrm{y}^{\mathrm{c}}$ admirall of flanders with a $\mathrm{xxx}$ gallant Shipes of warre well mand and also woll furnesshyd with gons and artelery and welcomyd and salutyd the Dukys grace not onely with plesunt and lovyng woriles but also with trumpis shames and shutyng of greyt peces of ordynances that it was greit wonder to here the greyt noyse of the sime gonis and so condutyd the Dukes ship to ryce banke by Calles where as thay of the Castell and also Ryce banke shotte greyle peces of ordynace and so wolcomed the Dules Grace lyke wyse to Callys whe[r]as he lay of turysday at nyght frydiny al day and of fryday at nyglt cansyd a trumpe to be sonde and proclamacion to be mado euery man to dysloge and to attend appon the Dukes Grace wher as he campt iiij Englyshe myles of on Callys in a place callyd Cakewell by peplyng within the Englysshe payle and there Campt Seturday all nyght and of Sonday the vj day of July whe removyd frome thens to a towen callyd whitsonby one the seeside within the freince kynges domynyon where as we champt Sonday

\footnotetext{
1 Blank in manuscript.
} 
monday Twysday Weddynsday Thirysday Fryday al day and of Seturday the xij day of July the Campe Removyd frome thence to Morgyson within vij myles of bullayn and there lay in Campe Sonday monday Tuysday where as our lyght horssemen had dyuers skyrmysshis with them of bullayn and dreve them in at the yattes of bullayn our Englyssemen slewe in the sayd Chase vj freincemen \& toke one \& ij of our lyght horssemen where slayne.

A seruant of Mr Eldyker for whome as mych none made 2

And of monday the xiij ${ }^{3}$ day of July the Kynges mayeste came to Calles aboute tho hower of vij of the cloke at nygltt where he was ryally recenyd with a greyt nomber of horssemen and archeres and of tuysday the $\mathrm{xv}$ day of July the Duke of Suffoke beyng the kynges leyftenant whent to Calles to his grace with whome whent a greyt nomber of horsse men of the Campe and there was thurysday and of fryday the xviij day of July the sayd lorde leyvetenant with the lorde marshall the lord marquie Dorsset Ryde to bullayn with the nomber of ccc horssemen cc hagbussheres iij hundryth archers and iij hundred pykys to weve $(s i c)$ the grounde where thay wold Campe before bullayn a certayn nomber of lyght horssemen and hagbussheres and archeres skyrmyssyd with the fiencemen Where as was a hote Skyrmysse for thay of the towen of bullayn Shoyte many peces at our horssemen but thay dyde lyttell hirte to them and lykewyse the hagbussheres but our hagbussheres and archeres shoyte so holy to gether that thei made them of the towen to go backe and so persued them to the yates of bullayne and slue and toke dyueres pesantes of the ffrencemen at the wyche Skyrmesse was slayen of our men hagbussheres a iij and so the lorde levetenant the lorde marques Dorsset the lorde marshall with there company for thatt day thay retournyd backe to Morgyson and of Seterday the xix day of July the lorde levetenant cavsyd a trump to be sounde vere erly in the mornyng to gyve bnowlage to all men to dyslodge and remove which mornyng was som what foule and mysty how be it or euer whe approchyd ny Bullayen it brake vppe so the foyte men came in good array of battell towardes the towen of bullayn the sayd levetenaunt levyng the lorde marques Dorsset with all the foyte that is to saye with ther archeres pykes \& byll men who brought them in good array towardes the towen of bullayen the lorde levetenant \& the lorde marshall ryd afore ryght valyenly to the towen of bullayen with a cc lyght horse men cc hagbussheres and cc archeres who skyrmysshed with the frencemen to suche tyme as the greyte peces of ordenance $\&$ a cc pyaneres approchyd the towen the greit gones so shotte to gether that the pyaneres kest vppe trenshey so that all way the greit peces came all ways ner \& ner the towen The horssemen hagbutteres \& archers shotte so to gether that the Frence horsemen \& hagbuteres intred the towen at wych entere ther where dyueres frencemen hagbuteres slaen one Englysseman slaen by a frenche hagbuter who stroke of the englyssemans hede thyngkyng to haue caryed the same in to bullayn but an englysse hagbuter was ware of his doyng \& shotte the ffrenceman thorow the body that there he lay for his pryde. This skyrmysse was vere hotte $\&$ in maner no frenceman durst appere appon the walles of the towen or at eny

2 This word is doubtful, being cut short and torn in the inner fold of the sheet,

S Sic, for 'xiiij.' 
bullwarke for fere of our greyt peces and hagbuteres who bette the bulwarkes viz the Greyn and New bulwarke the Churche the faire and greit howsis in the towen that it was wonder to all men to behold. There was neuer no suche assawt sene nor the lyke hayth not be harde of the peple of the towen cryed and fled owt of the other syde by basse bullayen and the see but as sone as our ambossche of horssemen who laye of that same syde slew dyueres and drove them yn to the see. And after certan of the sayd ambusche of lyghthorssemen ryde abrode in to the countre a bout bullayen and Gatte cc kye and steres and iijc schepe besydes other profytes thay gayte of the foytemen that flede owt of bullayn. This sayd xix day whe campe as nye the towen of bullayn as myght be and wherin campt with Caryges \& Gones that whe laye as sure as we have be in bullayn. All this day our gonneres never cest schutyng of there greyt peces. the Greyn bullwarke shotte in to the camp a monge hus $\&$ hurte the legges of somwhat and slew horssis and waggyneres and other hurt the sayd day thay of the towen dyde lyttell but shotte the toppes of somwhat of our tentes but hurt thay dyd none other then I haue sayd afore. The Sonday the $\mathrm{xx}$ day of July our pyaneres wroght sore a bout there and came within lxxx paces of the walles of bullayen where as our greyt peces where lyed and so shutte at the walles and howsis of the towen that thay brake and browysed them marvelusly sore.

The Monday the xxj of July hubberlyen capton of a c hagbutteres approchyd the wache tower standyng by the see syde entendyng to Gyve assawte therevnto and the sayd hubberdyen goyng to the tower was slane by a hagbutter of the tower and incontenent there appon ther issued owt of the towen of bullayn certayn Fraunce horssemen $\&$ hagbuteres and other gevyng the alarme our soldyeres as horssemen hagbutteres archeres and morres pykes with suche spede and so ernestly that the frenclimen recolyd in to baysse bullayne where our Englysse horssemen folowyd them in suche wyse that thei entryd in to the towen of bullayne. And the resydew of our souldyores abrode at this skyrmysh enteryd also in to bayse bullayne with myche danger. For the orderyng of what the lorde levetenant sent thetler Sir Edward Baynton to haue the cheyf reule of dyueres other gentlemen Captaynes wych where the lorde Jōhn Gray Mr Broughton $\mathrm{M}^{\mathrm{r}}$ Caundyshe Fraunces Askew Edmonde Hall and dyueres other hauyng there $\mathrm{xv}^{c}$ men Where for this monday and the next tuysday our souldyeres at the frenchemen and they at hus shotte vere hottlye bothe daye and nyght In the meayn tyme the pyoneres wroght to enclose basse bullayen with trenches ass well for the defences therof as to enclose vppe greyt bulloigne gates that our enemyes myght not yssue owt but with myche danger. but after theys ii days had bothe more rest and also had leasure to serche and ryfull the towen of bayse bulloigne where thay fonde myche baggage as whyeyt baken lynen and hytchen stuf and somme old ordynance all which for the more parte was had in celleres and walls of the howses next to greit bullaygne the howsis of which to hyde this spoyle the frenchemen brent to saue the goodes before our entere. Wedynsday the xxiij of July ordynance was sent to assalt the wache tower. Wher ${ }^{4}$ rppon thay who lepte it perceyved was forth with ylded or that eny pece of ordynance was slotte of in the which was $x y$ 
men of warre in maner as peasantes had as our presyneres the wache howse is a long old tower standyng by the see vppon a hyll of greyt leyght and no stayre to hit but ladderes. in it was nothyng but very baggis and vj or vij peces of ordynaunces but smale and vytel to haue serued those feowe soldyures for half a yere.

Thurisday a trompet came to the lorde levetenaunt from Monsieur de Vandon one of the cheyftaynes of france the cause of whose comyng not comonly declaryd. Ayenst this day our pyoneres had made a trench ayenst the gayte of greit bullaygne towardes Mutterell where at the frenche men not a lyttell offended dyd every day ayenst neynght enforced as wee gesse to seke forage for there horssis skymmysh with our gonners and archeres appontyd to kepe our trenche of which Sir George Carowe had thouersyght for our helpe where in was a Chapell adyoinyng to our trench which defended there gonshotte lyttell hurt on ether parte but dystrubyng of our people for the ffrenche men in mockery wold cryd bowes to rese our souldyeres in there gonshotte but ordyeres was taken for the stay of our men not to sturre butt uppon comandyment. fryday the xxv of July the frenche peasantes towardes nyght yssued the tow for thaving of forrage for there horsse and cattell where vppon dyueres of our horssemen were sent fourth which kyllyd dyueres of them being hagbutteres albeit slaves and dyuers were taken wherof iiij or $\nabla$ were very bold boyes. at this shyrmysche veale a tall gent of the lorde levetenantes was slayen with a half hake for whome many lamented as good cause.

Seterday the xxvj of July the kynges magestie came to bullaygne and encamped near the wache tower $w^{t}$ dyueres horssmen rnder a hill syde fro the gonne shott.

Sondaye the xxvij of July a seruante of $\mathrm{Mr}^{\mathrm{r}}$ pastons of the priuy chamber beyng a very talman was slaen with a Culveryn at the trenche being there onely to see whose name was morgayen.

The same daye at nyght a gent and his man with there ij horse were stryken at one shotte with a Culveryn and al emong there legges.

All theis iij days last past our men enforce the makyng of a monte a yenst the towen and our enemyes do mounte a greue bulwerke which is lyke to do myche harme.

Monday the xxviij of July wyldfycr was shottc of both partyes were of lyttell hurt folowyed as ys yet knoen this Sonday nyght there taken in stowketcll watche ij horssemen that issuid out of bullaigne.

Tuysday the xxix of July Sir Thomas Poyns and Sr Nyclos Ponynges by the lycense of the liynges maystie accompanyd w' certain yereshemen and dyneres of there one relynew approchid a lyttell castell yet very strong with in vi myles of bullaygne callyd [ i] wych albeit well mannyd is ordynancel which was vppon the somons therof yeld uppe. Condycion that their habytances there in myght savely goo with barg and baggage. where in the cattell is estemed to be of greate value. the kepyng of which is geven to peter Carow.

Wedrlynsday a gent messenger came frome the Firench kynge to gyve vs knowledge tluat he wold feyght with hus.

Thursday Fryday and Seterday there was somme Shotyng with gonnes and no greit hurte on neyther partie.

\footnotetext{
- Blant: in manuseript.
} 
Sonday the iij of August the greyt gonnes beyng bent vppon iij seuerall partes of the towen they beganne the battery which contyneued so hot that our enemyes beyng in danger of our gonne shotte dyd in maner syldom shotte from the towen.

Monday there apporched a greyt narye of shippes vppon the costes of bullayne but whense they ar yt is not yet perfectly lnowen but it is tought that be of ye spanysh fleit.

Tuysday $\mathrm{S}^{r}$ Anthony brown $\mathrm{w}^{\mathrm{t}}$ iijj foyte men and iijc horsemen havyng ij peces of greit of ordynaunces marchid erly in the mornyng to asault an abbay defended with frenchemen of warre, and also to Scowre the woodes abouth the same where appon Saterday last dyueres of our men bouth horsemen and foit men where taken and slayne.

Where the sayd $\mathrm{S}^{r}$ Anthony browen by fier whane the same where in were $\mathrm{xxx}^{\text {ti }}$ french souldyueres and the rest brent and slayne.

This sault contynew styll and dayle our men slayne and hurt emong which one burgoyn survayor of Callys captayn and setter fourth of the pyoneres workes was slayne by a gonne in the chappell trench calling at a lope hole for a goner to shuyt at a frenche man who in the meane dyspatchid him whose deth was myche lamentyd and the more for $y^{t}$ his devyse being wytty to convay men by trenches was not knowen. passe him ouer and speke of $y^{\mathrm{e}}$ french men that by day issued the towen to our trenchis where they slew one of our souldyeres and hurt ij being of $\mathrm{Mr}$ Longs retinew keping that tyme the trenche.

And further the tuysday the xix of August a crj Frenchemen sent from Hedyng castell to bulloyne travyld al the nyght $\mathrm{xxx}$ englyshe myles a horseback vppon lyttell nagges onely for that way wer a ij myles frome bullayne they left theym tyed together. themselves escaping our scowtes travelyd a fote tyll thay came to our trenches wtin ij stone cast of the towen wall where our foite watche espying them sett fourhe vppone them enforsyd theym to scatter whereat $\mathrm{xxx}^{\mathrm{ti}}$ where slayne $\delta$ xxviij were taken and whether the rest fled or entered the towen it is not presently knowen.

Wedynsday and Thurisday then next we gare hotte larins to the towen oone euere parte but to cause them to spend a greit parte of there provysion of gonne powther and wildficr.

\section{LETTERS OF TIIE CHEVALIER DE ST. GEORGE.}

Arong the Egerton MSS. in the British Muscum (no. 1609, fol. 28; no. 1677 , fol. $7,13,15,17,18,20,22,24$ ) are the following letters from the Chevalier, which, if of no great importance, are yet interesting in the refercnees they contain to Jacoljite matters and as an illustration of the Chevalier's kindly and courtly nature. Letter I. containsa sensible suggestion regarding the Irish regiments in the French service. I.jetter II. was written from Arignon three montlis after the Chcralier's return from Scotland upon the conclusion of Mar's ill-judged and ill-directed rising. It is possible that the affare qui me regarde plus personellement que tout les autres has reference to the pension 